\title{
Status of perceived social support and its associated factors among inmate prisoners in Northwest Amhara, Ethiopia
}

\author{
Abel Fekadu Dadi ${ }^{1,3}$, Berihun Assefa Dachew ${ }^{1,6}$, Amare Tariku², Yohannes Ayanaw Habitu ${ }^{4}$ \\ and Getu Debalkie Demissie $5^{5^{*}}$
}

\begin{abstract}
Objective: The objective of this study was to determine the level of social support and associated factors in selected prison institutions in Amhara region, Ethiopia.

Result: Prisoners that had good social support from their family, friends, and significant others were 64.7\%, (95\% $\mathrm{Cl} 60.9 \%, 68.4 \%)$. The odds of social support was higher among those educated and rural prisoners. However, it was found to be lower among non-Orthodox Christian prisoners and prisoners who were discriminated. Social support is buffering tool for social difficulties and hardships faced by prisoners while they are in prison and very helpful to reduce mental health morbidities and their consequences, hence should be strengthened.
\end{abstract}

Keywords: Social support, Prisoners, Crosses-sectional study

\section{Introduction}

Nearly 10 million people are in prisons worldwide this day and the number has been alarmingly increasing in most countries. The United State of America, China and Russia are the countries with the highest number of prisoners among developed countries while South Africa has the highest number of prisoners in Africa [1].

Prisoners shoulder a substantial burden of physical and psychiatric disorders compared to the general population. For example, the rate of depression among male and female prisoners in the United States is estimated to be $40 \%$ and $14 \%$ respectively, which is twice of the general population $[2,3]$. The problem also exist in low-income countries including Ethiopia [4-7]. Many of these disorders might present before admission to prison and further exacerbated by the stress of the imprisonment. However, mental disorders might also develop during

\footnotetext{
*Correspondence: getud2006@gmail.com

${ }^{5}$ Department of Health Promotion and Behavioral Health Sciences, College of Medicine and Health Science, University of Gondar, Gondar, Ethiopia

Full list of author information is available at the end of the article
}

imprisonment because of prevailing conditions possibly due to torture or other human rights violations $[8,9]$.

Social support is critical during their stay in the prison and post-release period to ease the transition, avoid recidivism and increase the likelihood of engaging in health risk practice without being affected with any psychological morbidities [10].

A number of studies so far showed social support as having a direct relationship with mental and physical well-being $[5,11-13]$. Studies conducted on the general population have also found that good social support is associated with postive mental and physical well-being [12]. For prisoners, social support might be required in order to prevent their guilty and homelessness feeling and maintain their physical as well as mental wellbeing [14]. Findings also revealed that different factors (sex, religious and education level) affect perceived social support of prison inmates [15-17].

Research that focused on determining the status of social support in prison population especially in Ethiopia is very nil. Prisoned population are more at risk of common mental disorder than the general population and because of the nature of reasons of imprisonment it could be very difficult for prisoners to maintain a support 
that they have been got before. So, the knowledge of how prisoners are supported and what are the factors affecting the level of their social support is very important to help organizations working on the mental wellbeing of prisoners. Therefore, the aim of this study was to assess the level of perceived social support and its predictors in selected correctional institutions in the northwest of Amhara region, Ethiopia.

\section{Main text \\ Methods \\ Study design and setting}

The institution based cross-sectional study was conducted to determine the status of social support and its associated factors among prison inmates found in prisons of North West Amhara regional state. Amhara regional state is among one of the 11 regions in Ethiopia with a total population of $19,602,512$. There are 30 correctional institutions in the region while 10 of them are found in the North West part. The numbers of prisoners found in 30 correctional institutions in the region were 22,590 while 7564 prison inmates were imprisoned in correctional institutions found in the Northwest of the region.

\section{Sample size determination and sampling procedure}

All prisoners found in selected prisons of the North West Amhara regional state were the study populations. Those prisoners who were seriously ill and unable to communicate were excluded from the study. The minimum sample size $(\mathrm{n})$ was computed by single population proportion formula $\left[n=\left[\left(Z_{a / 2}\right)^{2 *} P(1-P)\right] / d^{2}\right]$ by assuming $95 \%$ confidence level of $Z_{a / 2}=1.96$, margin of error $5 \%$, proportion (p) of $50 \%$ and the final sample size was estimated to be 662 . A 1.5 design effect was used by considering the multistage sampling technique and assuming that there was no as such big variations among the prisons included in the study.

Multi-stage sampling technique was employed to select the study participants. Three correctional institutions: Bahir Dar, DebreTabor, and Gondar were randomly selected from 10 found in the Northwest Amhara Regional state. The prisoner list in every correctional institution was used as a sampling frame to randomly and proportionally select prisoners from each prison.

\section{Data collection and data quality control}

Data were collected by using structured interview administered questionnaire and the data collection method was through face to face interview with prisoners. It had four parts. The first part contains sociodemographic characteristics of the prisoners. The second part contained measurement tools used to assess prisoners common mental morbidity (depression, psychological distress, and anxiety). The Generalized Anxiety Disorder 7-item (GAD-7) [scale ranging from zero (not at all) to three (nearly every day)] was used to measure anxiety [18].

The Patient Health Questionnaire (PHQ-9) which contained nine questions each measuring a problem that the prisoners bothered in the last 15 days were used to measure depression and its scale measurement ranges from zero (not at all) to three (nearly every day) [19]. The Kessler Psychological Distress Scale (K10) with five-level response was used to measure psychological distress [20]. Multidimensional scale of perceived social support (MSPSS) was used to measure the level of prisoner's social support, the main outcome variable. The tool contains 12 questions that used to assess social support that a prisoner got from his family, friends and significant others. Each item is scored from 1 (very strongly disagree to 7 (very strongly agree) [21].

Receiver operating characteristics (ROC) curve analysis was done by STATA version 12 software in order to determine a cut of the point with high sensitivity and specificity. An individual is considered as having good social support if he/she has a score above the cut-off value, which is 39 . The internal consistency of the outcome variable, Multidimensional scale of perceived social support (MSPSS), was checked by conducting a reliability test (Cronbach's Alpha: 0.952).

The third part of the questionnaire was asked to assess behavioral factors, which includes the history of substance use (like Alcohol use, Chat chewing, cigarette smoking, Shisha) of the prisoner. The last (fourth) part assessed prisoners Socio-economic and environmental factors.

Eight Bachelor of Science (B.Sc.) holder data collectors were recruited, trained, and collected the data. The tool was pretested. The collected data were reviewed and checked for completeness and consistency before data entry.

\section{Data processing and analysis}

Data were checked and entered by using Epi Info version 7 and imported to SPSS version 20 for further cleaning and univariate analysis. The cleaned data were exported to STATA version 12 for further analysis. Mixed effect logistic regression model was fitted to avoid the clustering effect within the prisons. Prisons effect means prisoners selected from the same correctional institution would share common environmental and prison related factors. Adjusted odds ratio (AOR) with its 95\% confidence interval was used to declare statistical significance between social support and associated factors. 


\section{Result}

Socio-demographic characteristics of the prisoner

Data was collected from 649 respondents with a response rate of $98 \%$. The median inter quartile range age (IQR) of the prisoners was 28 years [24-35] and the median year they would stay in the correctional institution (IQR) for a prisoner was 10 years $[3,12]$. Five hundred eighty-three (89.8\%) were male while $434(66.9 \%)$ of the prisoners were from urban part of the country. (Table 1 ).

\section{In prison related characteristics}

One hundred thirty-eight (21.3\%) prisoners were lifesentenced prisoners, 308 prisoners conduct religious practice usually while more than half (59.9\%) of the prisoners participate in income generating activities in the correctional institutions. Three hundred thirteen (48.2\%) prisoners have not recognised the reason for their imprisonment and majority $(85.8 \%)$ of the prisoners were not agree on the number of years they have to penalise (Table 2).

\section{Level of social support and associated factors}

In the current study, $420(64.7 \%)$ of the prisoners had good social support (95\% CI 60.9\%, 68.4\%) and from this $380(905 \%)$ of them were males. From 66 female prisoners, $6.16 \%$ of them had good social support. The study identified different factors that are positively and

Table 1 Socio-demographic characteristics of prisoners imprisoned in selected correctional institution of Northwest Amhara, Ethiopia

\begin{tabular}{lc}
\hline Explanatory variables & Frequency (\%) \\
\hline Sex & $583(89.8)$ \\
Male & $66(10.2)$ \\
Female & \\
Residence & \\
Urban & $434(66.9)$ \\
Rural & $215(33.1)$ \\
Religion & \\
Orthodox Christian & $584(90)$ \\
Others (Muslim, Catholic and Protestant) & $65(10)$ \\
Marital status & \\
Single & $306(47.1)$ \\
Married & $228(35.1)$ \\
Not live with their partners & $115(17.7)$ \\
Educational status & \\
Not read and write & $108(16.6)$ \\
Read and write & $97(14.9)$ \\
1-8 class complete & $129(19.9)$ \\
$9-12$ class complete & $206(31.9)$ \\
Certificate and above & $109(16.8)$ \\
\hline
\end{tabular}

Table 2 In prisoner related characteristics of prisoners imprisoned in selected correctional institution of Northwest Amhara, Ethiopia

\begin{tabular}{|c|c|}
\hline Explanatory variables & Frequency (\%) \\
\hline \multicolumn{2}{|l|}{ Type of prisoner } \\
\hline Life sentenced prisoner & $138(21.3)$ \\
\hline Other than life Sentenced prisoner & $511(78.7)$ \\
\hline \multicolumn{2}{|l|}{ Frequency of conduct religious practice } \\
\hline Always & $308(47.5)$ \\
\hline Sometimes & $229(35.3)$ \\
\hline Never & $112(17.3)$ \\
\hline \multicolumn{2}{|l|}{ Participate in income generating } \\
\hline Yes & $389(59.9)$ \\
\hline No & $260(40.1)$ \\
\hline \multicolumn{2}{|c|}{ Did you have a job before you become prisoner } \\
\hline Yes & $467(72.0)$ \\
\hline No & $182(28.0)$ \\
\hline \multicolumn{2}{|c|}{ Did you felt happy with your life until you become prisoner } \\
\hline Yes & $567(87.4)$ \\
\hline No & $82(12.6)$ \\
\hline \multicolumn{2}{|l|}{ Do you have a friend in the prison } \\
\hline Yes & $407(62.7)$ \\
\hline No & $242(37.3)$ \\
\hline \multicolumn{2}{|c|}{ Had you been discriminated because of your imprisonment } \\
\hline Yes & $283(43.6)$ \\
\hline No & $365(56.4)$ \\
\hline \multicolumn{2}{|l|}{ How often you feel guilty } \\
\hline Always & $354(54.5)$ \\
\hline Sometimes & $105(16.2)$ \\
\hline Never & $190(29.3)$ \\
\hline \multicolumn{2}{|c|}{ Perceived magnitude of mistake committed } \\
\hline Hard & $304(46.8)$ \\
\hline Medium & $152(23.4)$ \\
\hline Low & $193(29.7)$ \\
\hline \multicolumn{2}{|c|}{ Did you believe on the crime you have committed } \\
\hline Yes & $267(41.1)$ \\
\hline No & $313(48.2)$ \\
\hline I don't have any idea & 69 (10.6) \\
\hline \multicolumn{2}{|c|}{ Is the year you penalized is in line with your mistake } \\
\hline Yes & $30(4.6)$ \\
\hline No & $557(85.8)$ \\
\hline I don't have any idea & $62(9.6)$ \\
\hline \multicolumn{2}{|l|}{ Satisfaction with the care you obtain } \\
\hline Satisfied & $65(10)$ \\
\hline Medium satisfaction & $580(89.4)$ \\
\hline Low satisfaction & $4(0.6)$ \\
\hline \multicolumn{2}{|l|}{ Had previous psychiatric problem } \\
\hline Yes & $92(14.2)$ \\
\hline No & $557(85.8)$ \\
\hline \multicolumn{2}{|l|}{ Family history of mental illness } \\
\hline Yes & $84(12.9)$ \\
\hline No & $565(87.1)$ \\
\hline \multicolumn{2}{|c|}{ Did you use chat, shisha or cigarette smoking habit } \\
\hline Yes & $118(18.2)$ \\
\hline No & $531(81.8)$ \\
\hline
\end{tabular}


Table 3 Bivariate and multivariable logistic regression model fitted to identify factors associated with prisoner's social support among prisoners imprisoned in selected correctional institution of Northwest Amhara, Ethiopia

\begin{tabular}{llll}
\hline Explanatory variables & $\begin{array}{l}\text { Social } \\
\text { support }\end{array}$ & $\mathrm{COR}_{95 \% \mathrm{Cl}}$ & $\mathrm{AOR}_{95 \% \mathrm{Cl}}$ \\
& Good Poor & & \\
& &
\end{tabular}

\begin{tabular}{lrrll}
\hline Residence & & & & \\
$\quad$ Urban & 301 & 133 & 1 & 1 \\
Rural & 119 & 96 & $0.55(0.39,0.77)$ & $0.62(0.41,0.93)^{*}$ \\
Religion & & & & \\
$\quad$ Orthodox & 384 & 200 & 1 & 1 \\
$\begin{array}{l}\text { Others (Catholic, } \\
\quad \text { Muslim, Protestant) }\end{array}$ & 36 & 29 & $0.65(0.38,1.09)$ & $0.48(0.27,0.86)^{*}$ \\
Marital status of the prisoner & & & \\
$\quad$ Single & 211 & 95 & 1 & \\
$\quad$ Married & 143 & 85 & $0.75(0.53,1.09)$ & \\
$\quad$ Separated & 66 & 49 & $0.60(0.39,0.95)$ &
\end{tabular}

Educational status of the prisoner

$\begin{array}{lrrll}\text { Not read and write } & 50 & 58 & 1 & 1 \\ \text { Read and write } & 68 & 29 & 2.70(1.52,4.82) & 2.86(1.53,5.35)^{*} \\ \text { 1-8 class } & 76 & 53 & 1.66(0.99,2.79) & 1.51(0.84,2.70) \\ \text { 9-12 class } & 145 & 61 & 2.69(1.65,4.39) & 1.95(1.10,3.43)^{*} \\ \text { College and above } & 81 & 28 & 3.20(1.78,5.75) & 2.35(1.20,4.59)^{*}\end{array}$

Did you felt happy with your life until you become prisoner

$\begin{array}{lrrll}\text { Yes } & 377 & 190 & 1 & \\ \text { No } & 43 & 39 & 0.54(0.34,0.87) & \\ \begin{array}{lllll}\text { Do you have friend in this prison } & & & 1 \\ \text { Yes } & 292 & 115 & 1 & 1 \\ \text { No } & 128 & 114 & 0.45(0.32,0.63) & 0.48(0.33,0.70)^{* *}\end{array}\end{array}$

Have you been discriminated because of crime you have committed

$\begin{array}{lrrll}\text { Yes } & 162 & 121 & 0.54(0.39,0.75) & 0.55(0.38,0.80)^{* *} \\ \text { No } & 258 & 108 & 1 & 1 \\ \text { How often you feel guilty } & & & & 1 \\ \text { Always } & 236 & 118 & 1 & 1 \\ \text { Sometimes } & 73 & 32 & 1.08(0.67,1.74) & 0.91(0.54,1.55) \\ \text { Never } & 111 & 79 & 0.71(0.49,1.02) & 0.60(0.39,0.91)^{*}\end{array}$

Previous psychiatric problem

$\begin{array}{lrrl}\text { Yes } & 50 & 42 & 0.54(0.34,0.86) \\ \text { No } & 370 & 187 & 1\end{array}$

Family history of mental illness

$\begin{array}{lrrr}\text { Yes } & 49 & 35 & 0.66 \\ \text { No } & 371 & 194 & 1\end{array}$

$371 \quad 194$

Is there any impossibilities that prevent you to resettle to the previous state

\begin{tabular}{lrrll} 
Yes & 124 & 89 & $0.57(0.40,0.82)$ & $0.62(0.42,0.91)^{*}$ \\
No & 296 & 140 & 1 & 1 \\
Psychological distress & & & & \\
$\quad$ Distressed & 340 & 201 & 1 & \\
$\quad$ Not distressed & 80 & 28 & $1.71(1.07,2.75)$ & \\
$\begin{array}{l}\text { Depression } \\
\text { Depressed }\end{array}$ & 169 & 115 & 1 \\
Not depressed & 251 & 114 & $1.64(1.17,2.30)$ \\
\hline
\end{tabular}

Significance $(P$-value $) * * 0.01, * 0.05$ negatively associated with prisoners social support condition.

After adjusting to different factors: prisoner's residence before imprisonment (rural, $[\mathrm{AOR}=0.62,95 \% \mathrm{CI} 0.41$, 0.93 , religion being non-orthodox $[\mathrm{AOR}=0.48,95 \% \mathrm{CI}$ $0.27,0.86$ ] and educational status, [could be able to read and write, $(\mathrm{AOR}=2.86,95 \% \mathrm{CI} 1.53,5.35)$, completed 9-12 class (AOR $=1.95,95 \%$ CI 1.10, 3.43) and above college level $(\mathrm{AOR}=2.35,95 \% \mathrm{CI} 1.20,4.59)$, were significantly associated.

On top of that, having friend in the correctional institution $[\mathrm{AOR}=0.48,95 \% \mathrm{CI} 0.33,0.70]$, being discriminated by the social for his/her mistake[AOR $=0.55,95 \%$ CI $0.38,0.80]$, never feeling guilty $[\mathrm{AOR}=0.60,95 \% \mathrm{CI}$ $0.39,0.91]$ and impossibilities to be back to the previous state $[\mathrm{AOR}=0.62,95 \% \mathrm{CI} 0.42,0.91]$ were additional factors that affected the level of the prisoners social support (Table 3).

\section{Discussion}

Nearly two out of three inmate prisoners reported that they had got social support from their friends and families. This finding showed a low level of social support as compared to the expected level that this neglected people should have. Though the social support measurement tool had a wide dimension, still it was used to assess a support that a prisoner got from his/her family, friends in the prison and other near relatives being in that prison.

This study revealed that educational status was significantly associated with prisoners' social support. Prisoners who could read and write and more educated had significantly better in social support. This might happen because of persons with higher education level gave social value for his relatives. Other study also revealed that prisoners whose education level is beyond high school perceived that as having social support from his nearby persons [17].

The religion of the prisoner was also significantly affected the level of social support. Compared to other religious followers, orthodox religious followers were $52 \%$ higher to had good social support. A study conducted in Mississippi, prisoners who participated in Christians' religious epiphanies got social support through engagement with similar faith followers. The epiphany participation helped to develop social support networks [22]. Generally religious participation can contribute for social support as there is shared value among every member of the group [23].

This study also showed that lack of friends in prison increased the odds of poor social support. Prisoners who did not make any friend in the correction center had a significantly low level of social support. This might 
happen because of the fact that having friend would give a chance for the prisoner to get relatively better support. A nearby friend would share each other happiness and sorrow that he/she felt in the correctional center. Findings showed a positive correlation between social support from friends (both inside and outside of prison) [17].

In this study, one of the factors that significantly affected the level of prisoner social support was a residence. Prisoners from rural part had low social support compared to that of urban. This might happen because of the fact that relatives from the rural part would take a long distance to reach the prisoner. This would cost them money and longtime which would be difficult for them to afford. On top of that, the number and the quality of friends that the prisoner had during his life period might be also different for prisoners from urban and rural.

The other variables that had a significant association with social support were discrimination condition, feeling guilty about the crime, and the impossibility for the prisoner to resettle to their previous state. Accordingly, the odd of having social support was $45 \%, 40 \%$ and $38 \%$ times lower if the prisoner was discriminated by his/her socials, felt guilty about the crime he/she committed and if it is impossible for the prisoner to resettle to his/her previous state respectively. There is a study which showed that inmates may experience greater isolation and a sense of feeling forgotten by their families, communities, and society, resulting in a greater deficit of social support and a significant relationship between social support and psychological well-being, specifically with self-esteem [24].

\section{Limitation}

The major limitation of this study was, not using qualitative method to explore more information.

\begin{abstract}
Abbreviations
AOR: adjusted odds ratio; BSc: Bachelor of Science; COR: Crude Odds Ratio; GAD-7: Generalized Anxiety Disorder 7-item; IQR: interquartile range; MSPSS: multidimensional scale of perceived social support; PHQ-9: Patient Health Questionnaire; ROC: receiver operating characteristics.
\end{abstract}

\section{Acknowledgements}

We would like to express our great thanks and appreciations to study participants for their willingness to participate and provide required information in this study.

\section{Authors' contributions}

AFD, BAD and AT conceived, designed and coordinated the study, participated in data acquisition, analysis and interpretation and reviewed the manuscript. $\mathrm{YAH}$ and GDD participated in review the manuscript. All authors read and approved the final manuscript.

\section{Funding}

Not applicable.

\section{Availability of data and materials}

The data is found on the hands of first author and could be obtained upon reasonable request.
Ethics approval and consent to participate

Ethical clearance was obtained from the University of Gondar, College of medical and Health Sciences, Institutional Review Board. Informed written consent was obtained from each study participant prior to the interview.

\section{Consent for publication}

Not applicable.

\section{Competing interests}

The authors declare that they have no competing interests.

\section{Author details}

${ }^{1}$ Department of Epidemiology and Biostatistics, College of Medicine and Health Science, University of Gondar, Gondar, Ethiopia. ${ }^{2}$ Department of Human Nutrition, College of Medicine and Health Science, University of Gondar, Gondar, Ethiopia. ${ }^{3}$ School of Public Health, College of Medicine and Public Health, Flinders University, Adelaide, Australia. ${ }^{4}$ Department of Reproductive Health, College of Medicine and Health Science, University of Gondar, Gondar, Ethiopia. ${ }^{5}$ Department of Health Promotion and Behavioral Health Sciences, College of Medicine and Health Science, University of Gondar, Gondar, Ethiopia. ${ }^{6}$ Institute for Social Science Research (ISSR), The University of Queensland, Brisbane, Australia.

Received: 8 August 2019 Accepted: 3 October 2019

Published online: 17 October 2019

\section{References}

1. Walmsley R. World prison population list. 8th ed. London: King's College London International Centre for Prison Studies; 2009.

2. Binswanger IA, Merrill JO, Krueger PM, White MC, Booth RE, Elmore JG. Gender differences in chronic medical, psychiatric, and substancedependence disorders among jail inmates. Am J Public Health. 2010;100(3):476-82

3. McMurran M, Christopher G. Social problem solving, anxiety, and depression in adult male prisoners. Legal Criminol Psychol. 2009;14:101-7.

4. Ali Y, Yigzaw N, Bekana L, Mekonen S. Prevalence of common mental disorders and associated factors among prisoners in debre markos town correctional institution, North-West, Ethiopia. Int J Ment Health Psychiatry. 2016;2:2. https://doi.org/10.4172/2471-4372.1000118.

5. Beyen TK, Dadi AF, Dachew BA, Muluneh NY, Bisetegn TA. More than eight in every nineteen inmates were living with depression at prisons of Northwest Amhara Regional State, Ethiopia, a cross sectional study design. BMC Psychiatry. 2017;17:31.

6. Dachew BA, Fekadu A, Kisi T, Yigzaw N, Bisetegn TA. Psychological distress and associated factors among prisoners in North West Ethiopia: crosssectional study. Int J Mental Health Syst. 2015;9(1):39.

7. Dadi AF, Dachew BA, Kisi T, Yigzaw N, Azale T. Anxiety and associated factors among prisoners in North West of Amhara Regional State, Ethiopia. BMC Psychiatry. 2016;16(1):83.

8. Brugha T, Singleton N, Meltzer H, Bebbington P, Farrell M, Jenkins R, Coid J, Fryers T, Melzer D, Lewis G. Psychosis in the community and in prisons: a report from the British National Survey of psychiatric morbidity. Am J Psychiatry. 2005;162(4):774-80.

9. Holley HL, Arboleda-Flórez J, Love EJ. Lifetime prevalence of prior suicide attempts in a remanded population and relationship to current mental illness. Int J Offender Ther Comp Criminol. 1995;39(3):191-209.

10. Seal DW, Eldrige GD, Kacanek D, Binson D, MacGowan RJ. A longitudinal, qualitative analysis of the context of substance use and sexual behavior among 18- to 29-year-old men after their release from prison. Soc Sci Med. 2007:65:2394-406.

11. Helliwell JF, Putnam RD. The social context of well-being; philosophical transaction of the royal society of London series. Biol Sci. 2004;359:1435-46.

12. Uchino BN. Social support and health: a review of physiological processes potentially underlying links to disease outcomes. J Behav Med. 2006:29:377-87.

13. Lafferty L, Chambers GM, Guthrie J, Butler T. Indicators of social capital in prison: a systematic review. Health Justice. 2015;3:7. 
14. Goldstein EH, Warner-Robbins C, McCean C. A peer-driven mentoring case management community reentry model: an application for jails and prisons. Fam Community Health. 2009;32:309-13.

15. Haynie DL, Whichard C, Kreager DA, Schaefer DR, Wakefield S. Social networks and health in a prison unit. J Health Soc Behav. 2018;59(3):318-34.

16. Loper A, Gildea J. Social support and anger expression among incarcerated women. J Offender Rehabil. 2004;38(4):27-50.

17. Swanson C, Lee C, Sansone FA, Tatum KM. Prisoners' perceptions of father-child relationships and social support. Am J Crim Justice. 2012;37(3):338-55.

18. Spitzer RL, Kroenke K, Williams JBW, Löwe B. A brief measure for assessing generalized anxiety disorder, the GAD-7. Arch Inern Med. 2006;166:1092-7.

19. Kessler RC, Andrews GC. Short screening scales to monitor population prevalences and trends in non-specific psychological distress. Psychol Med. 2002;32:959-76.

20. Andrews G, Slade T. Interpreting scores on the Kessler Psychological Distress Scale (k10). Aust N Z J Public Health. 2001;25:494-7.
21. Gregory DZ, Nancy W, Sara G, Gordon K. The multidimensional scale of perceived social support. J Pers Assess. 1988;52:30-41.

22. Kerley K, Copes H. Keepin'My Mind Right. Int J Offender Ther Comp Criminol. 2009;53(2):228-44.

23. Putnam R. Bowling alone: the collapse and revival of American community. New York: Simon \& Schuster; 2000.

24. Beer A, Morgan R, Garland J, Spanierman L. The role of romantic/intimate relationships in the well-being of incarcerated females. Psychol Serv. 2007;4(4):250-61.

\section{Publisher's Note}

Springer Nature remains neutral with regard to jurisdictional claims in published maps and institutional affiliations.
Ready to submit your research? Choose BMC and benefit from:

- fast, convenient online submission

- thorough peer review by experienced researchers in your field

- rapid publication on acceptance

- support for research data, including large and complex data types

- gold Open Access which fosters wider collaboration and increased citations

- maximum visibility for your research: over $100 \mathrm{M}$ website views per year

At BMC, research is always in progress.

Learn more biomedcentral.com/submissions 